\title{
THE PRINCIPAL'S LEADERSHIP IN DEVELOPING THE RELIGIOUS VALUES IN SMA NEGERI 1 JATIROTO
}

\author{
Slamet Priyanto, Usman Zainuddin Urif, Wahyu Kurnia Utami \\ (STAI Bustanul Ulum Lumajang Jawa Timur ) \\ Panyaman@gmail.com, usmanzainuddinurif@gmail.com
}

\begin{abstract}
The values of religion in SMANJA recently is described as a school community which hasn't applied the values of religious (optimally/maximally) in daily life. The school life has not given the life based on the religious values taught by islam. The headmaster is trying to motivate all the school citizen to create/ develop the religious values and try to implement the values at school maximally. In daily life, most of school citizen do implement the religious values at school, for example: a) The activity of praying dzuhur and ashar, b) The activity of prayer Dhuha are not maximally implemented.

The goal of this research is to reveal the principal's leadership of developing the religious values in SMANJA. 1. Describing the religious values which are implemented in school community. 2. Describing the role and the effort of the principal in developing the religious values. 3. Describing the response of school citien in the offense of developing the religious values.

This research applies the qualitative research approach. The sources of the research are the school principal, the vice principal, the teachers, the TU staff, OSIS committee and Remush, while the data collecting methodology is done by observation, and documentation. The results of the research are analyzed by data reduction, data display and data verification.

The result of the research on the leadership in developing the religious values principal in SMAN Jatiroto including: 1. A calling for praying dhuhurwhichis done by the OSIS committee's member in turn. 2. Holding the Dhuhur/Ashar praying. 3. Celebrating the Islamic Religion Day. 4. Holding the examination DO'A together with students of XII grade and their parents face the national and school
\end{abstract}

Keywords : Principal's Leadership, Developing the Religious Values 


\section{INTRODUCTION}

Education constitute section can't allotted from life and human being life. Education a part faulty one necessary and fungtionsocial for human hold of role very important because can form temper and personality human mentioned until useful for directness the life in community. The basis education is something efforts so continue develop all potential humanity that able confront challenge life.

Education religion in particular education religion islam in a basis must include three aspect integrated, that is (1) knowing, that is in participant educate can know and to understand lesson and values religion (2) doing, that is in participant educate can practice of lesson and values religion (3) being, that is in participant educate can wolk on life appropriate with values and religion lesson ${ }^{1}$. Remember important education for human life, and then energy education must can supply to participant educate with life skill. (life skill or life competency) agree with area and necessary participant educate.

For give shape to aspect on be needned switch paradigm education religion in school. Muhaimin explain that be found switch paradigm education religion in school is that education religion not just mission teacher religion only. But constitute mission together between leadership school, religion teacher, general teacher, and an old fellow pupil. If education religion is mission together, useful education religion that necessary or in fact must to breed became culture school ${ }^{2}$.

Prepare situation that such, that character education religion islam necessary investigation with another energy in outside o'clock subject in the class as shape experience and efforts planting values Islamic to participant educate. That mean is values Islamic that became attitude and life mien reflection in personality participant educate every day until form character noble. Now efforts can do is with develop values religion in school, that mean all member school habituate self to put religion lesson in school so that became culture or cultural in school.

\footnotetext{
${ }^{1}$ Muhaimin, RekonstruksiPendidikan Islam (Jakarta: RajawaliPers, 2009), hlm. 39.

${ }^{2}$ Muhaimin, NuansaBaruPendidikan Islam MenguraiBenangKusutDuniaPendidikan (Jakarta: PT. Raja GrafindoPersada, 2006), hlm. 129
} 
Religious education Organization especially Islamic Religious Education in Law No 20 year 2003 about Nasional Education System and Government Rule that is operationally arrange implementation of that law. Therefore, the mention of terms "Islamic Education" can includes 4 perception ; 1) Islamic education in material understanding; 2) Islamic education in institution understanding, 3) Islamic education in culture and value understanding, 4) Islam education in education that's Islamic understanding ${ }^{3}$. For that we developed very important value of religions to do because that activity is an series of activity that can support the purpose of national education to reach and can affect students manner , behaviour and action indirectly.

Principal is the leader of education that have central role in carrying achievement of education institute because they have a role to guide, lead, conduct, build, motivating work, navigate organization, establishing good communication network with school community, environment. Based on review of the experts result about principal, can be said that principal is the key of the success of education in school $^{4}$.

Leadership as one of the management function is the thing that's very important to achieve organization purpose. Leadership is an important power in management, according to that, the ability to lead effectively (effective leader) is the key of the school success. A leader must have the ability to create the scene and athmopsher of condusive, safe, comfort, peace, un and full of spirit in work for worker and students. So the implementation of study activity can functionate orderly and smoothly in achieving hoped goal.

In related with creating the school athmosper of condusive, principal need to create the environment for its society to possibly used to applying religious lessons so it will become tradition for all school citizens. Principal role in developing religious values is very important. Because the education institute that managed by the leader who had strong religic commitment and wide conception will functionate dynamically as the progress of the times, beside that, principal is

\footnotetext{
${ }^{3}$ Halim Soebahar, Abdul, KebijakanPendidikan Islam, ( Jember : Pena Salsabila, 2012). Hlm, 2-3.

${ }^{4}$ Soetopo, HendyatSupervisiPendidikan (Jakarta: BumiAksara, 1984), hlm. 1.
} 
charged to understand the position of school in society, know agency and institute of societyThat support education, know social changing, economy, politic that all of that must be accompanied with deep faithfulness and taqwa also balanced with the ability to utilize information technology in this globalization era. Thus the principal in SMANJatiroto tried to developed values of religion in organization environment whom he led.

According to observing research, developing religious values in SMANJatiorot is the religious tradition that based on the faith of school citizen generally that all of them are Islamite. The moral problem and politeness are very pressured by the principal remembering how heavy the affection of the globalization and the futuristic technology that has been brought negative affection for students. That's why, the values of religions that emphasized in developing values of religions in school is the values of politeness, brotherhood, unity, mutual help, leadership of social care.

The existence of Jumat Prayer together in school's prayer room. The presence of the awareness to sadaqah trough charity box on Friday, besides that, there are still lots of other temporal religious activity, such as quick boarding school ramadhan activity, memorial of the Islamic big days (PHBI), and other stuff. There are the practice of values of religious that functionate really well and there are who doesn't go very well maximally, in example on implementing duhur prayer, ashar, duha, this thing is caused by the minimum of participation of homeroom teacher that's expected to take part to control their students as well as what is scheduled. According to the researcher assumption, participation is not implemented because the less of education teacher understanding that developing values of religions is the responsibility of all school citizens and must be admitted that Islamic religious education teachers are less fortunate to communicate it to education teachers. Values of religion that is pictured in SMAN 1 Jatiroto is running and civilizing in school environment is the form of support from the principal. Therefore in this research the researcher will describe empirically and deep about one of the leadership function, that is the process of planning that is done by the principal in developing values of religions in SMAN 1 Jatiroto. 


\section{PURPOSE OF LITERATUL}

The term definition is an explanation of the research concept in the research title ${ }^{5}$. The term definition is very useful to provide clear under standing and limits so that this research remains focused on the desired study. The term that need to be defined in this study are

1. Principal leadership Leadership in the general is a process when someone direct, guides, infulences, or controls, the thought, the feelings and the behaviorof others. While in particular, the definition of lesdeashipis : A person's personality that causes a group of others to imitate or to follow it, or leadership is personality that influences the authority in such a way that a group of people wants to do what they want ${ }^{6}$.

The headmaster can be defined as "a functional teacher who is given the task of leading a school where a teaching and learning process is held, or a place where there is interaction between the teacher who gives lessons and student who recive the lessons"7.

2. Develop religious values In developing religious values means creating a religious atmosphere or climate. In the contest of the school it means developing the atmosphere or climate of Islamic religious life, the impact of which is the development of a world view that influenced and inspired by the religious values an the teaching of islam that can be manifested by school citizen in daily life. From this definition, it can be seen that the scope of this research is limited to extinguish the leadership of the participal in developing religious values in SMAN JatirotoKabupatenLumajangEducation as planning organization, and supervision in fact until to evaluasi

The principal of school SMAN Jatiroto in his leadership efforts to expand the values of religion in school, should have mastered spiritval values. For the leader who has mastered spiritual values, the world is a journey to grow the seed of goodness which will be harvested after life, has cherished to other creatures.

\footnotetext{
${ }^{5}$ Wahidmurni, Menulis Proposal danLaporanPenelitianLapangan; PendekatanKualitatifdankuantitatifSkripsi, TesisdanDesertasi( Malang: PPs UIN Malang, 2008), hlm. 7.

${ }^{6}$ RB KhatibPahlawan Kayo, KepemimpinandanDakwah, ( Jakarta: Amzah, 2005), hlm. 7.

${ }^{7}$ Wahjosumidjo, KepemimpinanKepalaSekolah, (TinjauanTeoritikdanPermasalahannya) (Jakarta : PT Raja GrapindoPersada, 2010). 82
} 
For them the presence of some person is a gift that should be taken care of and improved not only social relationship but also more over become loveable and respectful relationship. The presence of others do not have a potensial chance to develop love among them

In the contextual eclucation at school, means that expand situation or religion life climate religion which will be influenced in expanding a religious value of life or in habitant by teaching and values religion shape into which in bearing life fiber skill life by rubber member school in life everyday. The religious values are clearly seen at this school, more over be from the researchchers point of view to expand the values religion as culture religion that can be shown by all the member of school. The habit of greeting, pray dhuha, dzuhur, and ashar(Pray togethere) in turns which scheduled by the religion teacher and all religion teacher islam. Infaq culture and sadaqah and pray togethere followed by all member school.

The values of religion important the principal of SMAN Jatiroto regard this values as one of factors for someone's success, he always give the school citizen us motivation and spirit. The importance of religious values in daily life not only in school society but also in a society these values will be the spirit of a series of activity that are being done.

\section{RESEARCH METHOD}

The type of approach used in this study is a qualitative approach to the type of field researchthat takes the location of District Suralaga East Lombok. For the purpose of the study, 7informants were selecting by purposive sampling. Data was collected using observation datacollection techniques, interviews and documentation.

\section{The result of the research examination and discussion}

\section{The values of religion which are developed by the principal in SMAN}

\section{Jatiroto}

The capability of somebody to show values religion in the life as a social skill which depend on the strenght or the weaknesses attitude of religious in him 
self, the religious attitude will be shown in form of action and behavior toward the society in accordance whit what are ordered by religious values in the way of developing the religious values which developed at school, according of researcher there are some components that can be used as idicators the religious attitude of in SMAN Jatiroto is:

a. Commitment about religion command and religion prohibition

b. Have a spirit deepen religion lessons good in school or in community

c. Active in all religious activity in school

d. Appreciate and pay close attention to the symbol sand slogans in which the are values religion lessons

e. Religion lessons as a source to expand idea and knowledge

According to the result of the research documentation, the researcher found the religious values which are developed in SMAN Jatiroto are:

1) Islamic values and worship, devout and devotion.

2) Example of values. (Uswah Hasanah)

3) Values hardwork, discipline, honesty.

4) Values the act off grateful, good works, shodaqoh.

5) Values of democracy, accurate life, a dravery to do a good deed

6) A dicipline values of appreciaty time should be applied to member school, because with commend time, school citizen and member school will not let time and opportunity got away they will use the time mzximally for doing some very useful activity them self or for somebody

7) The value of appreciating other's opinion should be given to the student therefore. In every meeting and discussion at school or community, the student will be able to apreciate other's opinion

8) The value of self confidence the principal of SMAN Jatiroto should implement to himself and the school citizen to be confidence and not to be easily influenced by the statement and the action of other people. The students must have an initiative and positive thinking. 
9) The value of beauty the principal of SMAN Jatiroto should always implement the valu of beauty to the school citizen by beautify the school environtment with the living healthy plants and flowers. By showing the value of beauty at school, every school citizen will feel comfortable at school

10) The value of politeness the princpal's leadership in implementing the value of politness observed by the researcher during his presence at school. As a principal, he could guard the school citizen to the youngest as well as to the adest.

11) The value of fullfilling a promise school citizen, tries coming on time and following the activities held in school based on the school,s rules, preventing the lateness in every aspect, in term of doing the task given by the teacher at school or at home

\section{2. leadership role and the principal's efforts in developing religious values in SMAN 1 Jatiroto}

The principal as a leader, in performing his role as educator, Principal has an important role in an effort to create school atmposhere that is can possibly push students improvement of faith and taqwa trough applying religious values in school. This role can be done by Principal trough management functions to education manager itself such as planning, organizationing, performing and inspecting even to evaluation.

SMAN 1 Jatiroto Principal in its leadership in an effort developing religious values in school, should be habing sipiritual maturity. For leadership who's having spiritual maturity, world is a trip to plant seed of goodness that later will be harvested in afterlife, having orientation to its affection against other creature. For them, someone else presence is a gift that must be preserve and improved. Not only social connection, but further being relationship that overlap affection and respect each other, The presence of others they do not have the potential to develop love and affection to its kind.

In education context in school, it mean developing atmosphere or climate of life and religious that the effect of it is developed a perception of 
life which imbued by the religious lessons or values that's realized in attitude also skills by the school citizens in daily life. Religious values above can be seen clearly in this school, how far the research oobservation in developing religious values as a religic culture can be shown by all school citizens. A culture like saying greetings and salam, duha prayer, zuhur and ashar jama'ah (in rotation) that scheduled by the imtaq coach and Islamic teacher infaq and sadaqah culture, zikir and praying together which followed by all school citizens.

Theres about worship values, the principal of SMAN 1 Jatiroto consider this values as one of the most important factor for the success of people. He always gives motivation and passion to all school citizens about how important the worship values in developing daily life wether in school environment or in society environment. This values will be the spirit for the chain of activites that's performed

\section{The Principal's effort in developing religious values as religic culture in}

\section{SMANJatiroto}

According to research observation through the field, about SMAN Jatiroto principal's effort in developing religious values as follows:

a. Organize imtaq activity continuosly every Friday to improve students faith and taqwa

b. Organize religious contest to celebrate isra' mi'raj.

c. Maintain the collaborative work with society in developing religious values

d. Infaq and sadaqah eveyday for teacher and students

e. Involving religious leaders and society in religious activities which are held in school as a it's for preacher or a prayer leader

f. Cooperate with society in an attempt to improveg the students' faith and taqwa

g. Organize Prayer Together toward UNBK and Exam also Arranging prostration of gratitude ( sujud syukur) along with Students Class XII 
every year the graduation, this activity held after receiving the results of UNBK

h. Organize expressed boarding school activity

i. Organize extracurricular activities that have characteristic like religious, students' talent and interest development of students such as rabanna qasidah and qiroatul qur'an

j. Through habituation the habitual activity to school citizens in applying religious values wether in school environment or its society

k. Displaying Islamic Song in every PHBI Activity

In ordertocreatica conducive/comfortable school environment for developing religious values by integrating or combine field of study besides Islamic Education, for improving students faith or taqwa, so in leading students to always have morals and implementing religious lessons not only become a responsible and duty from the Islamic education teacher, but all teachers should have known basic values that's set as a general guidance in arranging and developin school environment as theexpectation that so it will create a conducive religious culture and can be internalized by all school citizens.

Related to leadership of school principal in developing religious values as a religious culture in SMAN 1 Jatiroto by integrating common lesson.

1) Supportiny each other between general material with Imtaq material / value so that can be developed

There is a correlation Must be associated between knowledge concept with religious lesson which are related to other or support each other between general material content with imtaq material. For example fasting obligation need correction from health concept: health care need reinforcement from religious orders. Support each other can be formed by material selection or material lesson that's containing a possibility to grow values of faith and taqwa, such as choosing or making Islamic literature in Language lesson, Islamic song in KTK Lesson, Islamic 
term or Islamic in science lesson, using example of prayer shaf for material that's related with row.

2) If there's conflict between process/ learning material with imtaq value must be straightened.

Linkages should be existed if there's conflict content of lesson material between knowledge theory (concept) with religious teachings. For Example Conflict between evolution theory (in specific version) with theory of the creating human according to Al-Qur'an (according to specific version) or forbidden ham that's said by the cause of tapeworms in it, then all of that must be straightened. Other conflicts can be appeared because there's a conflict on process organizing educational activites with the value or a norm of religious teachings. Such as implementation of activities specifically that's related with the obligation to cover aurat for female students. Swim suit for baligh female students guided by a male teacher. So this conflict must be settled or straightened. If it's not settled or straightened, then psychologically students characteristics will be destroyed. On of the example of settlement is the female students who are not allowed to swim, but the female students must cover an aurat that's ordered by ALLAH SWT from Man's view. So it must be attempted that female students that's trained by female teacher in pool that's not a single man allowed.

3) Responde and Support from School Citizens toward School principal effort on Developing Religious Value in SMAN Jatiroto

Humans in its life needed a pole for a place to lean on, milestone's place depended on it, when a misery and disaster hit it or fail toachieve goal that's expected by it. Here is the Religious Role is very needed and Religion is present to give Strength, hope, will, optimist in life also giving fortitude when human face a narrowness and suffering. To know human needs toward religion can be seen among others from human's fitrah, then connect it with what a religion gives for fulfilling its needed.

The point of the education goal is faith and taqwa in making character and nation's civilization of Indonesia. On the basis of that, so all activity 
that's in school need to be arranged and containing purpose of faith and taqwa (imtaq) and developing science knowledge and technology that's have to be performed in continuous.

\section{CONCLUSION}

1. Religious Values that's developed by School Principal of SMAN 1 Jatiroto its indicator includes : Islamic Values and worship values, values of faith and taqwa, values of hardwork and honesty, values of smart gratitude and deed, solidarity and togetherness, democration, lives smart and doing good, respect other people opinion, beauty,politeness

2. Principal role and School Principal is Effort in developing Religious values in SMAN 1 Jatiroto, there are some efforts that's done: putting creed and moral lessons as local content lessons, organizing imtaq activity daily, religious contest every semester done, culturing infaq and sadaqah every day for teacher and students, organizing prayer together toward UNBK and Exam also prostration of gratitude (sujud syukur)with students class XII every year on graduatuopn after receieving announcement results, quick boarding school activity, extracurricular activity that's have religious characteristic, guidance rabanna qasidah and qiroatul qur'an, displaying Islamic song every PHBI Activity.

3. Respond and support toward developing Religious values from school principal's support, teachers, students, school committee, employee, in SMAN 1 Jatiroto

\section{REFERENCE}

Abdul, Halim Soebahar, 2012. KebijakanPendidikan Islam, Jember : Pena Salsabila

Muhaimin. 2009. Rekonstruksi Pendidikan Islam. Jakarta: Rajawali Press

Muhaimin.2006. Nuansa Baru Pendidikan Islam Mengurai Benang Kusut Dunia Pendidikan. Jakarta : PT. Raja Grafindo Persada 
RB Khatib Pahlawan Kayo, 2005. Kepemimpinan dan Dakwah. Jakarta: Amzah

Soetopo, Hendyat. 1984. Kepemimpinan dan Supervisi Pendidikan. Jakarta : BumiAksara

Wahidmurni.2008.Menulis Proposal dan Laporan Penelitian Lapangan; Pendekatan Kualitatif dan kuantitatif Skripsi, Tesis dan Desertasi. Malang: PPs UIN Malang

Wahjosumidjo. 2010. Kepemimpinan Kepala Sekolah, (Tinjauan Teoritik dan Permasalahannya). Jakarta : Rajawali Press 